cucumbers per tomato bed increases yield, in some cases. Kahn and Nelson (1991) demonstrated that trellised snow peas (Pisum sativum L.) grown in double rows produced a greater number and higher weight of fresh pods than plants grown in single rows.

\section{Literature Cited}

Baker, J.D. 1977. Trellising cucumbers. Agr. Gaz. New South Wales 88(4):2-3

Bhella, H.S. 1988. Tomato response to trickle irrigation and polyethylene mulch. J. Amer. Sot Hort. Sci. 113(4):543-546.
Bogle, C.R., T.K. Hartz, and C. Nunez. 1989. Comparison of subsurface trickle and furrow irrigation on plastic mulched and bare soil for tomato production. .I. Amer. Sot. Hart. Sci. 114( 1):4\& 43.

Hanna, H.Y., A.J. Adams, and R.J. Edling. 1989. Double-cropping cucumber and tomatoes to minimize the cost of staking cucumber. Proc. Florida State Hort. Sot. 102:326328.

Hanna, H.Y., A.J. Adams, and R.N. Story. 1987. Increased yield in slicing cucumbers with vertical training of plants and reduced plant spacing. HortScience 22(1):32-34

Khan, B.A. and W.A. Nelson. 1991. Row arrangement can affect yield and pod distribution pat- tern of trellised snow peas.HortScience26:532534.

Konsler, T.R. and D.L. Strider. 1973. The response of cucumber to trellis vs. ground culture. HortScience 8:32\&321.

Latin, R.X., J.E. Simon, and D.E. Matthew (eds.). 1984. Indiana vegetable production guide for commercial growers. Purdue Univ. Coop. Ext. Serv. ID-56.

Russo, V.M., B.W. Roberts, and R.J. Shatzer. 1991. Feasibility of trellised cucumber production. HortScience 26:115\&1 158.

U.S. Department of Agriculture. 1958. United States standards for grades of cucumbers. Agr. Mkt. Serv. 46 FR 63203.

\title{
Water Deficits and Fruiting Affect Carbon Assimilation and Allocation in Cucumber Plants
}

\author{
Abdul K. Janoudi ${ }^{1}$ and Irvin E. Widders ${ }^{2}$ \\ Department of Horticulture, Michigan State University, East Lansing, \\ MI 48824
}

Additional index words. Cucumis sativus, pickling cucumber, water deficit, stomatal conductance

\begin{abstract}
The effects of water deficit and fruiting on leaf gas exchange and dry-matter production and partitioning in cucumber (Cucumis sativus $\mathbf{L}$.) plants were evaluated in greenhouse and field experiments. Fruiting plants had higher photosynthetic rates (15.8 $\left.\mu \mathrm{mol} \cdot \mathrm{m}^{-2} \cdot \mathrm{s}^{-1}\right)$ than defruited plants $\left(12.7 \mu \mathrm{mol} \cdot \mathrm{m}^{-2} \cdot \mathrm{s}^{-1}\right)$. Although stomatal conductance was lower in defruited plants, it accounted for only $\approx 35 \%$ of the assimilation rate (A) reduction. Under water deficit, defruiting caused a similar response in $A$, even though $A$ was only $\approx 50 \%$ of that in watered plants. Fruiting and water deficits limited vegetative plant dry weight and total leaf area. In field experiments, removing flowers from the first four or eight nodes resulted in a higher count and fresh weight at harvest of only those pickling cucumber fruit that were irrigated.
\end{abstract}

Cucumber plant growth and development are highly sensitive to soil moisture depletion (Tan et al., 1983), because cucumber plants have a relatively shallow root system (Medina-Mora, 1987) and are unable to maintain high leaf water potential and relative water content (Behboudian, 1977). Water deficit during reproductive development limits the number of fruit set per plant, lowers the expansive growth rate of the fleshy fruit (Ortega and Kretchman, 1982), and increases the incidence of misshapen fruit and internal defects (Elkner, 1985).

Transient plant-water deficits also occur in cucumber plants under conditions conducive to high transpiration rates, such as those that might occur at mid-day (Behboudian

Received for publication 19Feb. 1992. Accepted for publication 19 Oct. 1992. The cost of publishing this paper was defrayed in part by the payment of page charges. Under postal regulations, this paper therefore must be hereby marked advertisement solely to indicate this fact.

${ }^{1}$ Visiting Research Associate, Plant Research Laboratory.

${ }^{2}$ Associate Professor; to whom reprint requests should be addressed.
1977). These water deficits result in leaf wilting, stomatal closure, and decreased photosynthesis (Nagoaka et al., 1984). Water deficits also affect assimilate partitioning among sinks in developing plants. Root growth is limited less than leaf and stem growth under mild water deficit (Forney and Breen, 1985; Hall and Milthorpe, 1978).

Conversely, the presence of developing fruit influences photosynthetic activity in lcavcs and assimilate partitioning in plants. Fruiting plants have higher photosynthetic rates than defruited (Barrett and Amling, 1978; Crafts-Brandner and Poneleit, 1987; Forney and Breen, 1985; Hall, 1977) or vegetative plants (Pharr et al., 1985). The comparatively high photosynthetic rates in fruiting plants have been attributed to higher stomatal (Gifford and Marshall, 1973; Rawson et al., 1976) or mesophyll (Hall and Milthorpe, 1978) conductance, or both. Growing cucumber fruit compete strongly with new leaves and stems for photoassimilates (Barrett and Amling, 1978; Pharr et al., 1985).

The combined effects of water deficit and fruit bearing on dry-matter allocation in cucumber plants have not been studied adequately. The objective of the present study was to gain an understanding of those effects as a step toward developing breeding or cultural management strategies for improving pickling cucumber crop performance under water deficit. Specifically, we determined the effects of water deficits and fruiting on leaf gas exchange and dry-matter production and partitioning in cucumber plants.

Greenhouse experiments were conducted from May to Aug. 1988 in the Plant Research Greenhouses, Michigan State Univ. (MSU), East Lansing. Seeds of the gynoecious pickling cucumber inbred Gy 14 were sown in a 1 peat (Baccto Professional Mix; Michigan Peat Co., Houston): 1 sandy loam mixture in 11-liter plastic containers. Plants received Peter's $20 \mathrm{~N}-$ 8.8P-16.6K soluble fertilizer (Grace-Sierra Horticultural Products Co., Milpitas, Calif.) twice weekly at $0.2 \mathrm{~g} \cdot \mathrm{liter}^{-1}$. Pistillate flowers were hand-pollinated using 'Sumter' staminate flowers between 10:00 AM to 12:00 PM each day during the flowering period. Day/ night temperatures were maintained at $30 / 20 \pm$ 5C; no supplemental lighting was provided. Water deficit treatments were initiated at anthesis by withholding water from the plants for 3 to 4 days, until the predawn water potential of the plants had reached -0.6 to $-0.8 \mathrm{MPa}$. Stressed and nonstressed plants received defruiting treatments. Fruit set was prevented by mechanically detaching pistillate flowers from plants daily throughout the experiment. Fruit from pollinated plants were harvested over 3 weeks when each fruit reached $4.5 \mathrm{~cm}$ in diameter. At 61 days after planting, all plants were harvested and separated individually into leaf lamina, stem plus petiole, and root fractions. Lcaf arca was measured using a leaf area meter (model LI-3000; LI-COR, Lincoln, Neb.). Dry weight was measured after plant tissue was dehydrated for $72 \mathrm{~h}$ in a forced-air oven at $60 \mathrm{C}$. The experiment design was a factorial randomized complete block with three replications and two plants per treatment.

Net $\mathrm{CO}_{2}$ assimilation rate (A), photosynthetically active radiation (PAR), relative humidity, and leaf temperature were measured using an LCA-2 (Analytical Development Corp., Hodesdon, England) portable, opensystem, infrared $\mathrm{CO}_{2}$ analyzer operated in differential mode, an air-flow rate of 600 $\mathrm{cm}^{3} \cdot \mathrm{min}^{-1}$, and a Parkinson broadleaf leaf chamber with a $6.25-\mathrm{cm}^{2}$ window area. Stomatal conductance $\left(\mathrm{g}_{\mathrm{s}}\right)$, transpiration rate $(\mathrm{E})$, 